\title{
Performance of grain sorghum hybrids in soils with low and high aluminum saturation ${ }^{1}$
}

\author{
Crislene Vieira dos Santos ${ }^{2}$, Nataly Sousa Silva ${ }^{3}$, \\ Jurandir Vieira Magalhães ${ }^{4}$, Robert Eugene Schaffert ${ }^{4}$, Cícero Beserra de Menezes ${ }^{4}$
}

\section{ABSTRACT}

The presence of aluminum $\left(\mathrm{Al}^{3+}\right)$ in acidic soils is one of the main causes of low crop yield, since it inhibits the root growth, thus affecting the nutrients and water uptake by plants. An approach to grow crops in areas with high $\mathrm{Al}^{3+}$ saturation is the use of tolerant cultivars. This study aimed to evaluate commercial sorghum hybrids in soils with low and high aluminum saturation, in order to select cultivars with high grain yield, even when exposed to abiotic stress. Twenty hybrids were evaluated for characteristics such as plant flowering, plant height and grain yield. All three traits were significantly affected by $\mathrm{Al}^{3+}$, being grain yield the most affected one. Despite the significant genotypes $\mathrm{x}$ environments interaction for grain yield, it was possible to select hybrids with yield above the national average in both environments. The hybrids BRS373, 50A50, AS4639, DKB540, AS4625, A9721R, 1167092, DKB550, $1 \mathrm{G} 282$ and AG1040 showed a high yield under low and high Al-saturation conditions.

KEYWORDS: Sorghum bicolor; abiotic stress; aluminum tolerance; plant breeding.

\section{INTRODUCTION}

Sorghum [Sorghum bicolor (L.) Moench] is the fifth most produced cereal in the world, after maize, wheat, rice and barley. In 2013, sorghum had an estimated world production of 61.4 million tons, in 42.1 million hectares (FAO 2015).

In Brazil, the acreage of grain sorghum is quite expressive, reaching a crop production of 2.1 million tons in an area of 722,000 hectares (Conab 2015). The consolidation of the sorghum crop in the country is due basically to the increased per capita consumption of animal protein, especially from swine, poultry

\section{RESUMO}

Desempenho de híbridos de sorgo granífero em solos com baixa e alta saturação por alumínio

A presença de alumínio $\left(\mathrm{Al}^{3+}\right)$ em solos ácidos é uma das principais causas da baixa produtividade das culturas, pois inibe $o$ crescimento das raízes, afetando a absorção de nutrientes e água pela planta. Uma abordagem para o cultivo em áreas com alta saturação por $\mathrm{Al}^{3+}$ é a utilização de cultivares tolerantes. Objetivouse avaliar híbridos comerciais de sorgo granífero em solos com baixa e alta saturação por $\mathrm{Al}^{3+}$, a fim de selecionar cultivares com alta produtividade de grãos, mesmo quando expostas a estresse abiótico. Avaliaram-se 20 híbridos, quanto às características de florescimento, altura de plantas e produtividade de grãos. As três características foram prejudicadas pelo $\mathrm{Al}^{3+}$, sendo a produtividade de grãos a mais afetada. Apesar de a interação genótipos x ambientes ser significativa para produtividade de grãos, foi possível selecionar híbridos com produtividade acima da média em ambos os ambientes. Os híbridos BRS373, 50A50, AS4639, DKB540, AS4625, A9721R, 1167092, DKB550, 1 G282 e AG1040 apresentaram alta produtividade nas condições de baixa e alta saturação por $\mathrm{Al}^{3+}$.

PALAVRAS-CHAVE: Sorghum bicolor; estresse abiótico; tolerância a alumínio; melhoramento de plantas.

and cattle; seed companies investment in developing hybrids adapted to the off-season; expansion of the no-tillage planting system; and effective actions of sorghum management by research and production agencies.

Over $90 \%$ of the national area of grain sorghum is located in the Brazilian Savannah region, as a succession crop after soybean, in the off-season. The remnants of the Brazilian Savannah vegetation developed on very old soils and are always associated with high acidity. Those soils are characterized by a high acidity, high $\mathrm{Al}^{3+}$ saturation and low availability of nitrogen $(\mathrm{N})$, phosphorus $(\mathrm{P})$, potassium $\left(\mathrm{K}^{+}\right)$,

1. Manuscript received in Aug./2017 and accepted for publication in Jan./2018 (http://dx.doi.org/10.1590/1983-40632018v4848851).

2. Universidade Federal de São João Del-Rei, Sete Lagoas, MG, Brasil.E-mail: cris-vieira15@hotmail.com.

3. Fundação Educacional Monsenhor Messias, Sete Lagoas, MG, Brasil.E-mail: natalysouza.192@gmail.com.

4. Empresa Brasileira de Pesquisa Agropecuária (Embrapa Milho e Sorgo), Sete Lagoas, MG, Brasil.

E-mails: jurandir.magalhaes@embrapa.br, robert.schaffert@embrapa.br, cicero.menezes@embrapa.br. 
calcium $\left(\mathrm{Ca}^{2+}\right)$, magnesium $\left(\mathrm{Mg}^{2+}\right)$, zinc $(\mathrm{Zn})$, boron (B) and copper $(\mathrm{Cu})$. Additionally, most Brazilian Savannah soils have reduced water-holding capacity (Silva \& Malavolta 2000).

Aluminum is one of the most abundant metals in the Earth's crust, being released into the soil solution under acidic conditions, taking over phytotoxic forms, like $\mathrm{Al}^{3+}$. The toxicity caused by $\mathrm{Al}^{3+}$ affects the development of plants and, in particular, inhibits the root growth, making the roots short and coarse. The root tip is the primary target of $\mathrm{Al}^{3+}$ (Kochian et al. 2004).

Besides being harmful to the growth of the root system, $\mathrm{Al}^{3+}$ interferes with the uptake of $\mathrm{P}, \mathrm{Ca}$ and $\mathrm{Mg}$ by plants, also contributing to the adsorption of $\mathrm{P}$ in the soil. High levels of $\mathrm{Al}^{3+}$ in soil with water deficiency reduce yield drastically, making cultivation impractical in areas of high acidity (Kochian et at. 2015).

An approach to the cultivation in areas with high $\mathrm{Al}^{3+}$ saturation is the use of tolerant cultivars. Plant breeding enables the increase of yield without the expansion of the area, resulting in economic and environmental benefits. The selection of sorghum hybrids with this characteristic would be an efficient alternative to facilitate the exploitation of areas with high $\mathrm{Al}^{3+}$ saturation (Caniato et al. 2007 and 2014).

There are already $\mathrm{Al}^{3+}$ tolerant hybrids in the market, but further studies continue to be developed to search for new sources of tolerance and better understand the effect of these genes in grain yield under $\mathrm{Al}^{3+}$ stress. Thus, this study aimed to evaluate commercial hybrids of grain sorghum in soils with low and high $\mathrm{Al}^{3+}$ saturation, in order to identify those with high grain yield, even when exposed to $\mathrm{Al}^{3+}$ stress. The selected genotypes have no previous information about $\mathrm{Al}^{3+}$ tolerance.

\section{MATERIAL AND METHODS}

The trials were carried out at the aluminumphenotyping site of the Embrapa Milho e Sorgo, in Sete Lagoas, Minas Gerais state, Brazil, being sown on 23 March 2015 and harvested on 15 August 2015. The site is located at $767 \mathrm{~m}$ above the sea level and has an average annual rainfall of $1,400 \mathrm{~mm}$, as well as temperatures ranging from $17^{\circ} \mathrm{C}$ to $25^{\circ} \mathrm{C}$.

Nineteen commercial hybrids of grain sorghum (BRS 373, BRS 330, BRS 332, $1 \mathrm{G} 100,1 \mathrm{G} 282$,
50A50, 50A70, AG 1040, AG 1060, AS 4625, AS 4639, DKB 540, DKB 550, Jade, 80G80, BM 737, Buster, FOX and A 9721R) and one experimental hybrid (1167092) were grown under two aluminum $\left(\mathrm{Al}^{3+}\right)$ saturation conditions ( $0 \%$ and $40 \%$ ). BRS 330 was used as the control.

The experimental design was a randomized complete block, in a 2 × 20 factorial scheme $\left(\mathrm{Al}^{+3}\right.$ saturation $\mathrm{x}$ hybrids), with three replications. Plots consisted of 4 rows of $5 \mathrm{~m}$, with $0.5 \mathrm{~m}$ between rows. Plots were thinned to $12 \mathrm{~cm}$ between plants $(180,000$ plants ha-1).

The experimental area, with different levels of $\mathrm{Al}^{3+}$ saturation, was set according to Menezes et al. (2014). Dolomite limestone with $33 \%$ of $\mathrm{CaO}$ and $14 \%$ of $\mathrm{MgO}$ was broadcasted over the entire area and disked to a depth of $20 \mathrm{~cm}$, in order to achieve an exchangeable $\mathrm{Al}^{3+}$ saturation of $0 \%$. No limestone was needed in the area with $40 \%$ of $\mathrm{Al}^{3+}$ saturation. Two months after liming, the area was divided into rectangular $10 \mathrm{~m} \times 10 \mathrm{~m}$ and $5 \mathrm{~m} \times 5 \mathrm{~m}$ grids, for the control and $\mathrm{Al}^{3+}$ toxicity site, respectively. A total of 51 and 169 points were sampled in the control and $\mathrm{Al}^{3+}$ toxicity site, respectively. Three subsamples located in a maximum radius of $1.0 \mathrm{~m}$ from each sampling grid point were collected and the compound samples were used for the soil analysis. The measurements of soil exchangeable aluminum $\left(\mathrm{Al}^{3+}\right)$ and exchangeable cations $\left(\mathrm{Ca}^{+2}, \mathrm{Mg}^{+2}\right)$ were performed with $\mathrm{KCl}$ $1 \mathrm{~mol} \mathrm{~L}^{-1}$ as extractor (Donagema et al. 2011), using inductively-coupled argon plasma (ICP) emission spectrometry. Percent values of $\mathrm{Al}^{3+}$ saturation were calculated as the ratio of exchangeable $\mathrm{Al}^{3+}$ divided by the sum of basic cations plus $\mathrm{Al}^{3+}$. The two areas presented means of $\mathrm{Al}^{3+}$ saturation of $0 \%$ and $40 \%$. In the area with $0 \%$ of $\mathrm{Al}^{3+}$ saturation, the soil analysis presented $\mathrm{pH}$ of 5.7, $23 \mathrm{mg} \mathrm{dm}^{-3}$ of $\mathrm{P}\left(\right.$ Mehlich $\left.^{-1}\right)$ and $223 \mathrm{mg} \mathrm{dm}^{-3}$ of $\mathrm{K}\left(\right.$ Mehlich $\left.^{-1}\right)$, while a $\mathrm{pH}$ of 4.8 , $15 \mathrm{mg} \mathrm{dm}^{-3}$ of $\mathrm{P}\left(\right.$ Mehlich $\left.^{-1}\right)$ and $51 \mathrm{mg} \mathrm{dm}^{-3}$ of K $\left(\mathrm{Mehlich}^{-1}\right)$ were observed in the area with $40 \%$ of $\mathrm{Al}^{3+}$ saturation. Starter fertilizers were applied using $400 \mathrm{~kg} \mathrm{ha} \mathrm{l}^{-1}$ of $08-28-16\left(\mathrm{~N}-\mathrm{P}_{2} \mathrm{O}_{5}-\mathrm{K}_{2} \mathrm{O}\right)+\mathrm{Zn}$. At the sixth-leaf stage, $250 \mathrm{~kg} \mathrm{ha}^{-1}$ of urea $(44 \%$ of $\mathrm{N})$ were side dressed in all the area.

Weeds were managed with atrazine (2-chloro4-ethylamine-6-isopropylamine-s-triazine) at $3.0 \mathrm{~kg} \mathrm{ha}^{-1}$, and hand hoeing was used as needed, in order to control additional weeds during the study.

The other crop managements were carried out according to recommendations for sorghum crop 
(Menezes et al. 2015b). After the grain filling stage, panicles were protected with polyethylene bags, to prevent bird damage. Harvest was carried out mechanically, after the grains reached physiological maturity.

The following traits were measured: days to flowering (estimated by counting the number of days between sowing and the moment when more than $50 \%$ of the plants achieved anthesis), plant height (obtained by measuring the distance between the ground and the apex of the panicle after the physiological maturity) and grain yield (estimated by weighing the grain mass, corrected to $13 \%$ of moisture, transforming the results to $\mathrm{tha}^{-1}$ ).

Data were submitted to the individual variance analysis, considering the effect of the hybrids and $\mathrm{Al}^{3+}$ saturation as fixed. As the ratio between the greatest and the smallest mean square of the individual variance analysis did not exceed the 7:1 ratio, the joint analysis of the trials was performed (Banzatto \& Kronka 2006). Statistical analyses were performed using the Genes software (Cruz 2006), and the ScottKnott test $(p>0.05)$ was used to group the hybrids.

\section{RESULTS AND DISCUSSION}

The effects of hybrids and environments were significant for all three traits evaluated, indicating a differential performance of the hybrids in both conditions of low and high $\mathrm{Al}^{3+}$ saturation (Table 1). The effect of $\mathrm{Al}^{3+}$ (environments) is expected, since the $\mathrm{Al}^{3+}$ saturation changes the plant physiology, affecting the root development (Kochian et al. 2004) and, consequently, grain yield. The hybrids $x$ environments interaction was non-significant, what implies that the relative performance of the genotypes is not affected by $\mathrm{Al}^{+3}$. Therefore, genotypes selected under low $\mathrm{Al}^{3+}$ saturation also have a superior performance under high $\mathrm{Al}^{3+}$.

The coefficients of variation were low for days to flowering (3.7\%) and plant height (5.4\%), and intermediate for grain yield (19.3\%). This last trait, due to its polygenic control, is more influenced by environment and usually presents higher coefficients of variation. Despite this, the value is within the range recommended for plant breeding trials.

The average of days to flowering were 67 and 69 , respectively under $0 \%$ and $40 \%$ of $\mathrm{Al}^{3+}$ saturation. Even though this difference was low, it was significant. The flowering of the hybrids ranged from 60 to 72 days after sowing under low $\mathrm{Al}^{3+}$ saturation, and from 61 to 78 under high saturation (Table 2). Most of the hybrids reached flowering earlier than 70 days, which is an intermediate cycle. The characteristic days to flowering neither drops nor selects the hybrid, because it is important that the grower has cultivars with different cycles, in order to allow the scheduling of sowing and harvesting, thus optimizing his machinery and labor. However, hybrids with flowering later than 75 days must be avoided. In general, it is recommended that the grower starts sowing late maturity hybrids in the beginning of the season and finalize planting those earlier ones. The former have a higher yield potential and the latter, even yielding less, are indicated to finish the season, once they will spend less time in the field and suffer less risk of water stress, a recurrent fact at the end of the off-season (Menezes et al. 2015a).

Despite the significant hybrids $x$ environments interaction for days to flowering, the earliest hybrids were common in both environments (Table 2). The average grouping test ranked the hybrids in three and four flowering groups, respectively under low and

Table 1. Summary of the joint variance analysis (Anova) for days to flowering, plant height and grain yield of twenty sorghum hybrids evaluated under low and high aluminum saturation.

\begin{tabular}{|c|c|c|c|c|}
\hline \multirow{2}{*}{ Source of variation } & \multirow{2}{*}{ D.F. } & Flowering (days) & Plant height $(\mathrm{cm})$ & Yield $\left(\mathrm{t} \mathrm{ha}^{-1}\right)$ \\
\hline & & \multicolumn{3}{|c|}{ Mean squares } \\
\hline Hybrids (H) & 19 & $89.47 * *$ & $551.80 * *$ & $3.44 * *$ \\
\hline Environments (E) & 1 & $58.80 * *$ & $4,183 \cdot 10^{* *}$ & $30.82 * *$ \\
\hline $\mathrm{H} \times \mathrm{E}$ & 19 & $10.69^{*}$ & $88.26 * *$ & $0.48^{\mathrm{ns}}$ \\
\hline Error & 76 & 6.34 & 39.38 & 0.43 \\
\hline Mean control $^{1}$ & & $67.10 \mathrm{a}$ & $122.00 \mathrm{~b}$ & $3.90 \mathrm{~b}$ \\
\hline Mean stress ${ }^{2}$ & & $68.50 \mathrm{~b}$ & $110.15 \mathrm{a}$ & $2.89 \mathrm{a}$ \\
\hline $\mathrm{CV}(\%)$ & & 3.71 & 5.41 & 19.34 \\
\hline
\end{tabular}

**, Significant at $1 \%$ and $5 \%$, respectively, by the $\mathrm{F}$-test; ${ }^{\mathrm{ns}}$ non-significant; ${ }^{1} 0 \%$ of $\mathrm{Al}^{+3}$ saturation; ${ }^{2} 40 \%$ of $\mathrm{Al}^{+3}$ saturation. 
high $\mathrm{Al}^{3+}$ saturation. The hybrids FOX, Buster and $1 \mathrm{G} 100$ were the earliest ones, with flowering up to 62 days, in both conditions. BRS373 was also among the earliest in high $\mathrm{Al}^{3+}$ saturation. Only three hybrids showed differences for flowering between the two $\mathrm{Al}^{3+}$ saturations: the hybrid 1G282 was earlier under low $\mathrm{Al}^{3+}$ saturation, while DKB550 and $80 \mathrm{G} 80$ were earlier under high $\mathrm{Al}^{3+}$ saturation.

Plants under low $\mathrm{Al}^{3+}$ saturation were taller than under high $\mathrm{Al}^{3+}$ saturation. The mean grouping test divided the hybrids into three and four groups, with plants varying $99.2-142.5 \mathrm{~cm}$ and $87.5-130 \mathrm{~cm}$ tall, respectively under low and high $\mathrm{Al}^{3+}$ saturation (Table 3). All the hybrids presented plant height within the limits recommended for grain sorghum. Plant height is positively correlated with grain yield in sorghum. Nevertheless, the seed market demands a plant between $100 \mathrm{~cm}$ and $150 \mathrm{~cm}$ tall, because harvest is done using the same machine for soybean, which performs between these ranges. In addition, plants taller than $150 \mathrm{~cm}$ are more susceptible to lodging, causing losses in grain quality, besides increasing labor to harvest and time waste (Santos et al. 2005). Some hybrids presented shorter plants

Table 2. Averages of days to flowering of twenty hybrids of grain sorghum evaluated under low and high $\mathrm{Al}^{3+}$ saturation.

\begin{tabular}{|c|c|c|c|}
\hline & \multirow{2}{*}{ Hybrids } & \multicolumn{2}{|c|}{ Flowering (days) } \\
\hline & & $0 \% \mathrm{Al}$ & $40 \% \mathrm{Al}$ \\
\hline 1 & BRS 373 & $64.3 \mathrm{bA}^{*}$ & $63.3 \mathrm{aA}$ \\
\hline 2 & BRS 330 & $70.7 \mathrm{cA}$ & $70.7 \mathrm{cA}$ \\
\hline 3 & BRS 332 & $70.3 \mathrm{cA}$ & $72.0 \mathrm{cA}$ \\
\hline 4 & $1 \mathrm{G} 100$ & $61.0 \mathrm{aA}$ & $61.0 \mathrm{aA}$ \\
\hline 5 & $1 \mathrm{G} 282$ & $72.3 \mathrm{cB}$ & $65.7 \mathrm{bA}$ \\
\hline 6 & $50 \mathrm{~A} 50$ & $67.0 \mathrm{cA}$ & $67.3 \mathrm{cA}$ \\
\hline 7 & $50 \mathrm{~A} 70$ & $70.3 \mathrm{cA}$ & $70.0 \mathrm{cA}$ \\
\hline 8 & AG 1040 & $68.0 \mathrm{cA}$ & $71.3 \mathrm{cA}$ \\
\hline 9 & AG 1060 & $69.7 \mathrm{cA}$ & $70.7 \mathrm{cA}$ \\
\hline 10 & AS 4625 & $70.7 \mathrm{cA}$ & $70.7 \mathrm{cA}$ \\
\hline 11 & AS 4639 & $70.0 \mathrm{cA}$ & $72.7 \mathrm{cA}$ \\
\hline 12 & DKB 540 & $70.0 \mathrm{cA}$ & $71.0 \mathrm{cA}$ \\
\hline 13 & DKB 550 & $71.7 \mathrm{cA}$ & $77.7 \mathrm{~dB}$ \\
\hline 14 & Jade & $64.0 \mathrm{bA}$ & $66.3 \mathrm{bA}$ \\
\hline 15 & $80 \mathrm{G} 80$ & $64.0 \mathrm{bA}$ & $68.7 \mathrm{cB}$ \\
\hline 16 & BM 737 & $65.3 \mathrm{bA}$ & $69.3 \mathrm{cA}$ \\
\hline 17 & Buster & $60.7 \mathrm{aA}$ & $62.0 \mathrm{aA}$ \\
\hline 18 & FOX & $60.0 \mathrm{aA}$ & $60.7 \mathrm{aA}$ \\
\hline 19 & A $9721 \mathrm{R}$ & $65.0 \mathrm{bA}$ & $68.7 \mathrm{cA}$ \\
\hline 20 & 1167092 & $67.7 \mathrm{cA}$ & $71.0 \mathrm{cA}$ \\
\hline
\end{tabular}

* Means followed by the same lowercase letter in the column and capital letter in the row do not differ from each other by the Scott-Knott test at $5 \%$. under the stress condition, but, in general, almost all stayed within the standard accepted by the national market.

The trait most affected by high $\mathrm{Al}^{3+}$ saturation was grain yield, with a reduction of $26 \%$, when comparing the environment of high and low $\mathrm{Al}^{3+}$ saturation (Figure 1). The grain yield averages were $3.9 \mathrm{t} \mathrm{ha}^{-1}$ and $2.9 \mathrm{t} \mathrm{ha}^{-1}$, respectively in the environments with low and high $\mathrm{Al}^{3+}$ saturation (Figure 1 and Table 4). That reduction corroborates previous studies carried out under field conditions. Menezes et al. (2014) observed a reduction of $29.5 \%$ in grain yield, in an environment with $40 \%$ of $\mathrm{Al}^{3+}$ saturation, in relation to another with $0 \%$ of $\mathrm{Al}^{3+}$. Baligar et al. (1989) found a reduction of $24 \%$, in comparison to environments with low (2\%) and high (41\%) $\mathrm{Al}^{3+}$ saturation.

The mean grouping test divided the hybrids into three and two groups, with yield ranging 2.1-5.1 tha $\mathrm{ha}^{-1}$ and 1.2-4.0 $\mathrm{tha}^{-1}$, respectively in the environments with low and high $\mathrm{Al}^{3+}$ saturation (Table 4). Considering the national sorghum yield average of $2.8 \mathrm{t} \mathrm{ha}^{-1}$ (Conab 2015), $94 \%$ of the hybrids under low $\mathrm{Al}^{3+}$ saturation and $64 \%$ of the

Table 3. Average plant height of twenty hybrids of grain sorghum evaluated under low and high $\mathrm{Al}^{3+}$ saturation.

\begin{tabular}{rllr}
\hline & \multirow{2}{*}{ Hybrids } & \multicolumn{2}{c}{ Plant height $(\mathrm{cm})$} \\
\cline { 3 - 4 } 1 & BRS 373 & $122.5 \mathrm{cA}^{*}$ & $115.0 \mathrm{cA}$ \\
2 & BRS 330 & $123.3 \mathrm{cA}$ & $120.0 \mathrm{dA}$ \\
3 & BRS 332 & $117.5 \mathrm{cB}$ & $100.8 \mathrm{bA}$ \\
4 & $1 \mathrm{G} \mathrm{100}$ & $118.3 \mathrm{cB}$ & $100.0 \mathrm{bA}$ \\
5 & $1 \mathrm{G} \mathrm{282}$ & $142.5 \mathrm{~dB}$ & $130.0 \mathrm{dA}$ \\
6 & $50 \mathrm{~A} 50$ & $120.8 \mathrm{cA}$ & $115.0 \mathrm{cA}$ \\
7 & $50 A 70$ & $107.5 \mathrm{aA}$ & $101.7 \mathrm{bA}$ \\
8 & AG 1040 & $128.3 \mathrm{cB}$ & $115.0 \mathrm{cA}$ \\
9 & AG 1060 & $99.2 \mathrm{aB}$ & $87.5 \mathrm{aA}$ \\
10 & AS 4625 & $125.0 \mathrm{cA}$ & $125.0 \mathrm{dA}$ \\
11 & AS 4639 & $125.8 \mathrm{cB}$ & $110.0 \mathrm{cA}$ \\
12 & DKB 540 & $127.5 \mathrm{cA}$ & $120.8 \mathrm{dA}$ \\
13 & DKB 550 & $121.7 \mathrm{cB}$ & $102.2 \mathrm{bA}$ \\
14 & Jade & $126.7 \mathrm{cB}$ & $114.2 \mathrm{cA}$ \\
15 & $80 G 80$ & $111.7 \mathrm{bB}$ & $90.8 \mathrm{aA}$ \\
16 & BM 737 & $120.8 \mathrm{cA}$ & $113.3 \mathrm{cA}$ \\
17 & Buster & $130.0 \mathrm{cB}$ & $98.3 \mathrm{bA}$ \\
18 & FOX & $130.0 \mathrm{cB}$ & $113.3 \mathrm{cA}$ \\
19 & A 9721 R & $128.3 \mathrm{cA}$ & $119.2 \mathrm{dA}$ \\
20 & 1167092 & $111.7 \mathrm{bA}$ & $110.8 \mathrm{cA}$ \\
\hline
\end{tabular}

* Means followed by the same lowercase letter in the column and capital letter in the row do not differ from each other by the Scott-Knott test at $5 \%$. 
hybrids under high $\mathrm{Al}^{3+}$ saturation presented yield above the average.

Despite the significant hybrids $\mathrm{x}$ environments interaction for grain yield, it was possible to find hybrids with yield above the average in both environments. Grain yield is graphically depicted in Figure 2, in which the $\mathrm{x}$ axis shows the yield under low $\mathrm{Al}^{3+}$ saturation and the $\mathrm{y}$ axis the yield under

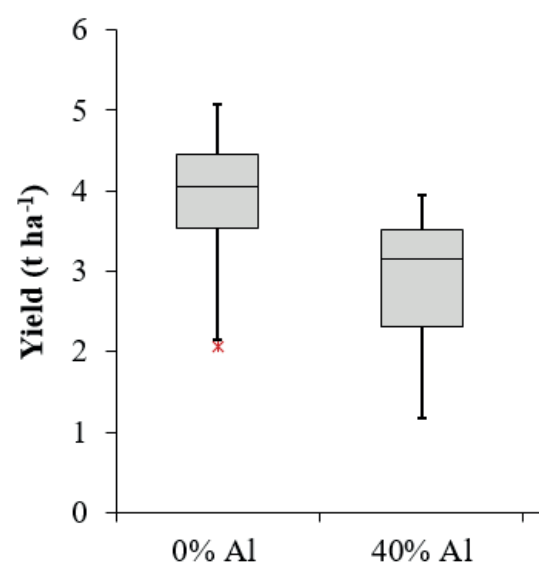

Figure 1. Box plot of grain yield for twenty sorghum hybrids evaluated under low and high $\mathrm{Al}^{3+}$ saturation. * Minimum outlier.

Table 4. Average grain yield of twenty hybrids of grain sorghum evaluated under low and high $\mathrm{Al}^{3+}$ saturation.

\begin{tabular}{rlll}
\hline & \multirow{2}{*}{ Hybrids } & \multicolumn{2}{c}{ Grain yield $\left(\mathrm{kg} \mathrm{ha}^{-1}\right)$} \\
\cline { 3 - 4 } & \multirow{2}{*}{ BRS $373 \mathrm{Al}$} & $40 \% \mathrm{Al}$ \\
2 & BRS 330 & $3,519 \mathrm{aA} *$ & $3,952 \mathrm{aA}$ \\
3 & BRS 332 & $3,242 \mathrm{bA}$ & $3,216 \mathrm{aA}$ \\
4 & $1 \mathrm{bA} 100$ & $4,178 \mathrm{aA}$ & $2,635 \mathrm{aA}$ \\
5 & $1 \mathrm{G} 282$ & $4,099 \mathrm{aA}$ & $3,108 \mathrm{aA}$ \\
6 & $50 \mathrm{~b} 50$ & $4,838 \mathrm{aA}$ & $3,879 \mathrm{aA}$ \\
7 & $50 A 70$ & $2,072 \mathrm{cA}$ & $1,279 \mathrm{bA}$ \\
8 & AG 1040 & $4,487 \mathrm{aB}$ & $3,065 \mathrm{aA}$ \\
9 & AG 1060 & $4,077 \mathrm{aA}$ & $2,846 \mathrm{aB}$ \\
10 & AS 4625 & $3,930 \mathrm{aA}$ & $3,533 \mathrm{aA}$ \\
11 & AS 4639 & $4,950 \mathrm{aA}$ & $3,804 \mathrm{aB}$ \\
12 & DKB 540 & $4,092 \mathrm{aA}$ & $3,657 \mathrm{aA}$ \\
13 & DKB 550 & $5,069 \mathrm{aA}$ & $3,275 \mathrm{aB}$ \\
14 & Jade & $3,200 \mathrm{bA}$ & $2,068 \mathrm{bB}$ \\
15 & $80 \mathrm{G} 80$ & $3,654 \mathrm{bA}$ & $2,325 \mathrm{bB}$ \\
16 & BM 737 & $2,559 \mathrm{cA}$ & $1,593 \mathrm{bA}$ \\
17 & Buster & $3,585 \mathrm{bA}$ & $1,168 \mathrm{bB}$ \\
18 & FOX & $3,679 \mathrm{bA}$ & $3,280 \mathrm{aA}$ \\
19 & A 9721 R & $4,438 \mathrm{aA}$ & $3,521 \mathrm{aA}$ \\
20 & 1167092 & $4,028 \mathrm{aA}$ & $3,292 \mathrm{aA}$ \\
\hline
\end{tabular}

* Means followed by the same lowercase letter in the column and capital letter in the row do not differ from each other by the Scott-Knott test at $5 \%$. high $\mathrm{Al}^{3+}$ saturation. The graphic is divided into four quadrants, according to the methodology proposed by Fageria \& Baligar (1993). In the upper left quadrant (A) are the tolerant hybrids that are non-responsive to environment improvement; in the upper right quadrant (B) the most promising hybrids, i.e., those that are tolerant and responsive to environment improvement; in the lower left quadrant (C) the susceptible and non-responsive hybrids; and in the lower right quadrant (D) the hybrids susceptible and responsive to the environment.

In the quadrant $\mathrm{A}$, two tolerant hybrids nonresponsive to the improvement of the environment were found. Six hybrids were classified in the quadrant $C$ as susceptible and non-responsive. In the quadrant $\mathrm{D}$, two hybrids proved to be susceptible and responsive to the environment improvement.

The hybrids of the quadrant B (BRS373, 50A50, AS4639, DKB540, AS4625, A9721R, 1167092, DKB550, $1 \mathrm{G} 282$ and AG1040) are the most important ones, due to the fact that they showed yield above the average in both environments, and can be considered as tolerant and responsive to the environment improvement. No hybrid of the quadrant $\mathrm{B}$ is among the earliest flowering ones. Only BRS 373 presented flowering earlier than the general average in both $\mathrm{Al}^{3+}$ conditions

Comparing the two $\mathrm{Al}^{3+}$ saturation environments, BRS330 and AS4625 presented a

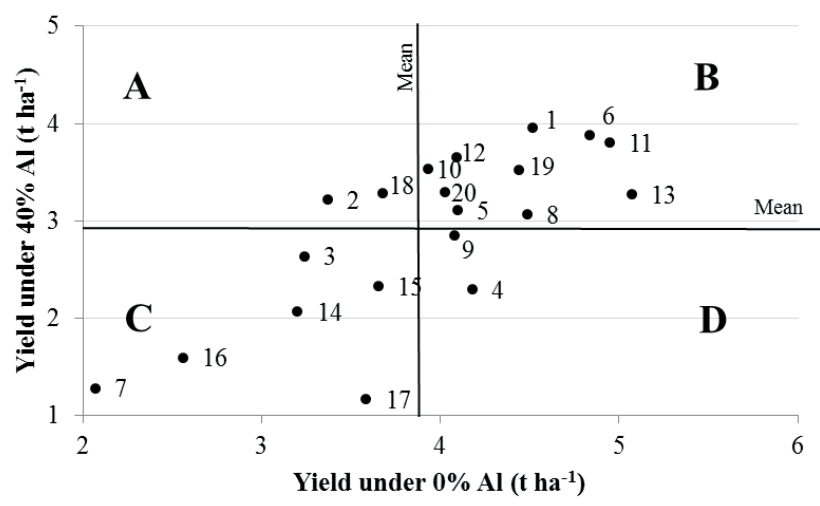

Figure 2. Dispersion diagram for grain yield of twenty sorghum hybrids evaluated under $0 \%$ (x axis) and $40 \%$ (y axis) of $\mathrm{Al}^{3+}$ saturation. Quadrant A: identifies hybrids that had low yield at $0 \%$ and high yield at $40 \%$ of $\mathrm{Al}^{3+}$ saturation; B: hybrids with high yield at both $0 \%$ and $40 \%$ of $\mathrm{Al}^{3+}$ saturation; $\mathrm{C}$ : hybrids with low yield at both $0 \%$ and $40 \%$ of $\mathrm{Al}^{3+}$ saturation; D: hybrids with high yield at $0 \%$ and low yield at $40 \%$ of $\mathrm{Al}^{3+}$ saturation. See number legends in Table 2. 
reduction lesser than $10 \%$ (Table 4). On the other hand, Buster and 1G100 presented a reduction above $40 \%$. The hybrids in quadrant B had less than $25 \%$ of yield reduction, except for AG1040 (32\%). The hybrids BRS330, DKB550 and AG1040 were classified as $\mathrm{Al}^{3+}$ tolerant in a previous study (Menezes et al. 2014), and all hybrids from the quadrant $\mathrm{B}$ have a yield statistically similar to it.

In sorghum, the major $\mathrm{Al}^{3+}$ tolerance locus $\left(A 1 t_{\mathrm{SB}}\right)$ was mapped to the end of sorghum chromosome 3, what explains a large proportion of the phenotypic variation for the $\mathrm{Al}^{3+}$ tolerance assessed in hydroponics (Magalhães et al. 2004). $\mathrm{Alt}_{\mathrm{SB}}$ is a major gene of the Multidrug and Toxic Compound Extrusion (MATE) family that confers tolerance to aluminum in sorghum (Magalhães et al. 2007). $\mathrm{Al}^{3+}$ tolerance involves the release of organic acids as malate and citrate, which form stable and non-toxic complexes with $\mathrm{Al}^{3+}$, thereby providing a means for plants to withstand $\mathrm{Al}^{3+}$ toxicity (Kochian et al. 2004). Studies have confirmed that the $\mathrm{Alt}_{\mathrm{SB}}$ gene in sorghum cultivars used in regions with acid soils or subsoils contributes to the development of better and deeper root systems and promotes a greater and sustainable yield. Carvalho Júnior et al. (2015), evaluating isogenic hybrids, found a stronger effect of $\mathrm{Alt}_{\mathrm{SB}}$ with a yield advantage of $0.5 \mathrm{tha}^{-1}$ in hybrids arising from one $\mathrm{Al}^{3+}$ tolerance Alt $_{\mathrm{SB}}$ allele.

In the present study, comparing the two environments (low and high $\mathrm{Al}^{3+}$ saturation), the reduction in the yield average, considering the hybrids from quadrants $\mathrm{A}$ and $\mathrm{B}$, was of $0.72 \mathrm{t} \mathrm{ha}^{-1}$, while, for the hybrids from quadrants $\mathrm{C}$ and $\mathrm{D}$, it was of $1.51 \mathrm{t} \mathrm{h}^{-1}$. Therefore, high $\mathrm{Al}^{3+}$ saturation reduces the grain yield in sorghum, but tolerant hybrids have lower losses, when compared to susceptible ones.

\section{CONCLUSION}

Ten hybrids (BRS373, 50A50, AS4639, DKB540, AS4625, A9721R, 1167092, DKB550, $1 \mathrm{G} 282$ and AG1040) outperformed the check cultivar under low and high aluminum conditions.

\section{REFERENCES}

BALIGAR, V. C. et al. Aluminum effects on growth, grain yield and nutrient use efficiency ratios in sorghum genotypes. Plant and Soil, v. 116, n. 2, p. 257-264, 1989.
BANZATTO, D. A.; KRONKA, S. N. Experimentação agrícola. 4. ed. Jaboticabal: Funep, 2013.

CANIATO, F. F. et al. Association mapping provides insights into the origin and the fine structure of the sorghum aluminum tolerance locus, AltSB. PLoS One, v. 9, n. 1, p. 1-12, 2014.

CANIATO, F. F. et al. Genetic diversity for aluminum tolerance in sorghum. Theoretical and Applied Genetics, v. 114, n. 5, p. 863-876, 2007.

CARVALHO JÚNIOR, G. et al. Back to acid soil fields: the citrate transporter SbMATE is a major asset for sustainable grain yield for sorghum cultivated on acid soils. G3 Genes, Genomes, Genetics, v. 6, n. 2, p. 475-484, 2015.

COMPANHIA NACIONAL DE ABASTECIMENTO (Conab). Acompanhamento de safra brasileira: grãos, décimo segundo levantamento, Setembro. Brasília, DF: Conab, 2015.

CRUZ, C. D. Programa Genes: estatística experimental e matrizes. Viçosa: Ed. UFV, 2006.

DONAGEMA, G. K. et al. Manual de métodos de análise de solo. Rio de Janeiro: Embrapa Solos, 2011.

FAGERIA, N. K.; BALIGAR, V. C. Screening crop genotypes for mineral stresses. In: WORKSHOP ON ADAPTION OF PLANTS TO SOIL STRESSES, 1993, Lincoln. Proceedings.... Lincoln: University of Nebraska, 1993. p. 142-162.

FOOD AND AGRICULTURE ORGANIZATION OF THE UNITED NATIONS (FAO). FAOSTAT production crops. 2015. Available at: <http://faostat.fao.org/site/567/ DesktopDefault.aspx?PageID $=567$ \#ancor $>$. Access on: 28 Oct. 2015.

KOCHIAN, L. V. et al. Plant adaptation to acid soils: the molecular basis for crop aluminum resistance. Annual Reviews of Plant Biology, v. 66, n. 1, p. 571-598, 2015.

KOCHIAN, L. V.; HOEKENGA, O. A.; PINEROS, M. A. How do crop plants tolerate acid soils?: mechanisms of aluminum tolerance and phosphorous efficiency. Annual Review of Plant Biology, v. 55, n. 1, p. 459-493, 2004.

MAGALHÃES, J. V. et al. A gene in the multidrug and toxic compound extrusion (MATE) family confers aluminum tolerance in sorghum. Nature Genetics, v. 39, n. 9, p. 1156-1161, 2007.

MAGALHÃES, J. V. et al. Comparative mapping of a major aluminum tolerance gene in sorghum and other species in the Poaceae. Genetics, v. 167, n. 4, p. 19051914, 2004.

MENEZES, C. B. et al. Combining ability of grain sorghum lines selected for aluminum tolerance. Crop Breeding and Applied Biotechnology, v. 14, n. 1, p. 4248, 2014. 
MENEZES, C. B. et al. Evaluation of grain yield in sorghum hybrids under water stress. Genetics and Molecular Research, v. 14, n. 4, p. 12675-12683, $2015 \mathrm{a}$.

MENEZES, C. B.; SILVA, A. F.; TARDIN, F. D. Sorgo safrinha. In: PEREIRA FILHO, I. A.; RODRIGUES, J. A. S. (Eds.). Sorgo: o produtor pergunta, a Embrapa responde. Brasília, DF: Embrapa, 2015b. p. 293-308. (Coleção 500 perguntas, 500 respostas).
SANTOS, F. G.; CASELA, C. R.; WAQUIL, J. M. Melhoramento do sorgo. In: BORÉM, A. Melhoramento das espécies cultivadas. 2. ed. Viçosa: Ed. UFV, 2005. p. 605-812.

SILVA, A. R.; MALAVOLTA, E. A conquista do Cerrado. In: PATERNIANI, E. (Org.). Agricultura brasileira e pesquisa agropecuária. Brasília, DF: Embrapa, 2000. p. 31-44. 